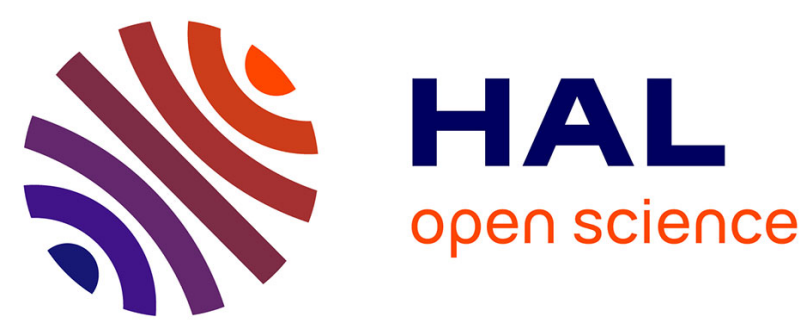

\title{
LANGERHANS CELL HISTIOCYTOSIS: ORAL/PERIODONTAL INVOLVEMENT IN ADULT PATIENTS
}

Susanna Annibali, Maria Paola Cristalli, Marco Solidani, Domenico Ciavarella, Gerardo La Monaca, Maria Michela Suriano, Lorenzo Lo Muzio, Lucio Lo Russo

\section{To cite this version:}

Susanna Annibali, Maria Paola Cristalli, Marco Solidani, Domenico Ciavarella, Gerardo La Monaca, et al.. LANGERHANS CELL HISTIOCYTOSIS: ORAL/PERIODONTAL INVOLVEMENT IN ADULT PATIENTS. Oral Diseases, 2009, 15 (8), pp.596. 10.1111/j.1601-0825.2009.01601.x . hal00517934

\section{HAL Id: hal-00517934 \\ https://hal.science/hal-00517934}

Submitted on 16 Sep 2010

HAL is a multi-disciplinary open access archive for the deposit and dissemination of scientific research documents, whether they are published or not. The documents may come from teaching and research institutions in France or abroad, or from public or private research centers.
L'archive ouverte pluridisciplinaire HAL, est destinée au dépôt et à la diffusion de documents scientifiques de niveau recherche, publiés ou non, émanant des établissements d'enseignement et de recherche français ou étrangers, des laboratoires publics ou privés. 


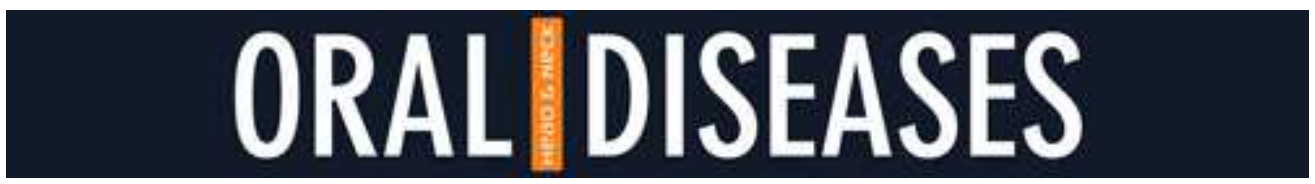

\section{LANGERHANS CELL HISTIOCYTOSIS: ORAL/PERIODONTAL INVOLVEMENT IN ADULT PATIENTS}

\begin{tabular}{|r|l|}
\hline Journal: & Oral Diseases \\
\hline Manuscript ID: & ODI-02-09-OM-1186.R2 \\
\hline Manuscript Type: & Original Manuscript \\
\hline Author: & 22-May-2009 \\
\hline Complete List of Authors: & $\begin{array}{l}\text { Annibali, Susanna; University "La Sapienza", Rome, Department of } \\
\text { Odontostomatologic Sciences } \\
\text { Cristalli, Maria; University "La Sapienza", Rome, Department of } \\
\text { Odontostomatologic Sciences } \\
\text { Solidani, Marco; University "La Sapienza", Rome, Department of } \\
\text { Odontostomatologic Sciences } \\
\text { Ciavarella, Domenico; University of Foggia, Department of Surgical } \\
\text { Sciences } \\
\text { La Monaca, Gerardo; University "La Sapienza", Rome, Department } \\
\text { of Odontostomatologic Sciences } \\
\text { Suriano, Maria; University of Foggia, Department of Surgical } \\
\text { Sciences } \\
\text { Lo Muzio, Lorenzo; University of Foggia, Surgical Sciences } \\
\text { Lo Russo, Lucio; University of Foggia, Department of Surgical } \\
\text { Sciences }\end{array}$ \\
\hline Keywords: & \begin{tabular}{l} 
Mucosa < Anatomic site, Periodontium < Anatomic site, Oncology \\
\hline
\end{tabular} \\
\hline \hline
\end{tabular}


Title page

\section{LANGERHANS CELL HISTIOCYTOSIS: ORAL/PERIODONTAL INVOLVEMENT IN ADULT PATIENTS}

Running title: adult oral histiocytosis

\begin{tabular}{ll} 
Susanna & Annibali $^{1}$ \\
Maria Paola & Cristalli $^{1}$ \\
Marco & Solidani $^{1}$ \\
Domenico & Ciavarella $^{2}$ \\
Gerardo & La Monaca $^{1}$ \\
Maria Michela & \multicolumn{1}{c}{ Suriano $^{2}$} \\
Lorenzo & Lo Muzio $^{2}$ \\
Lucio & Lo Russo $^{2}$
\end{tabular}

1. Department of Odontostomatologic Sciences, University “La Sapienza”, Rome, Italy

2. Department of Surgical Sciences, University of Foggia, Foggia, Italy

\section{Corresponding author:}

Dr. Lucio Lo Russo

Via Serro D’Annunzio, 55

83050 Vallesaccarda (AV) - Italy

Phone and Fax $+39(0) 881588041$

E-mail: lorusso.lucio@tiscali.it

1.lorusso@unifg.it

Source of funding: the present study was funded by authors' own institutions.

Conflict of interest: none 


\title{
LANGERHANS CELL HISTIOCYTOSIS: ORAL/PERIODONTAL INVOLVEMENT IN ADULT PATIENTS
}

\begin{abstract}
Objective: Langerhans cell histiocytosis (LCH) is a clonal proliferative multisystem disease. Although bone and mucosae have been classified as non-risk organs, their involvement may increase the risk of disease progression. Oral and periodontal lesions are burdened with a significant impairment of quality of life for associated signs, symptoms and loss of function. Most of information regards pediatric disease; the disease in adults has received limited attention.

Subjects and Methods: 31 adult patients affected by immuno-histopathology confirmed LCH have been prospectively examined; attention was paid to the occurrence and characterisation of oral lesions.

Results: 12 patients developed oral lesions. Posterior regions of jawbones were always affected; the involvement of anterior regions was not constant. Unifocal oral involvement was significantly associated with multisystemic disease while multifocal lesions were associated with unisystemic disease. Oral disease presented with soft tissues ulcers (50\% of cases), gingival bleeding (66.7\%), pain $(83.4 \%)$, periodontal damage $(50 \%)$, tooth mobility $(16.7 \%)$, non-healing extraction socket $(8.3 \%) ; 41.6 \%$ of patients complained of negative outcomes on quality of life. Oral lesions were easily handled with local measures.
\end{abstract}

Conclusions: Posterior regions require attention; single oral lesions may be part of multisystemic disease; oral and periodontal lesions may be early signs of disease reactivation.

Keywords: langerhans cell histiocytosis; jaw lesions; oral lesions; adult; treatment; 


\section{LANGERHANS CELL HISTIOCYTOSIS: ORAL/PERIODONTAL INVOLVEMENT IN} ADULT PATIENTS

\section{INTRODUCTION}

Eosinophilic granuloma, Hand-Schüller-Christian disease and Abt-Letterer-Siwe disease are three different clinical disorders characterised by an abnormal proliferation of histiocytes; they were grouped in 1953 by Lichtenstein under the name of histiocytosis $\mathrm{X}$ basing on a common histopathologic feature: the presence of cytoplasmic bodies known as X bodies(Hicks \& Flaitz, 2005, Arico et al., 2003). The disorder was renamed to Langerhans cell histiocytosis (LCH) in 1973 when Nezelof proved these histiocytes to be Langerhans cells (Bartnick et al., 2002). The disorder is characterized by a diffuse infiltration of large mononuclear cells, resembling histiocytes, with indistinct cytoplasmic border and rounded or indented vesicular nuclei, and a variable number of eosinophils; plasma cells, as well as lymphocytes and multinucleated giant cells may also be present. According to The Working Group of the Histiocyte Society a definitive LCH diagnosis can be set when, in addition to these light microscopy features, Birbeck granules can be detected in lesional cells by electron microscopy, and/or a positive staining for CD1a antigen can be obtained(Arico et al., 2003, Favara \& Jaffe, 1994). The definition of the extent of the disease by adequate work-up(McClain, 1999-2005) is fundamental; in fact, treatment planning and prognosis mostly rely on it (Giona et al., 1997), together with the age of patient at the disease onset. The disease occurring in adults (estimated incidence: from one to two cases per million(Baumgartner et al., 1997)) has received limited attention(Arico, 2004, Baumgartner et al., 1997, Malpas \& Norton, 1996, Howarth et al., 1999) especially for treatment protocols standardization and outcomes evaluation. Great emphasis has been placed on the characterization of "risk organs" (liver, spleen, lung, bone marrow) involvement; among "non-risk organs" (skin, mucosae, lymph nodes), oral manifestations received very little attention (Devaney et al., 1997, Milian et al., 2001). The latter encompass a variety of lesions involving jawbones, oral soft tissues and periodontium; due to the high frequency and the wide range of implications, they may significantly impair patient's quality of life, have the potential for early diagnosis improvement and contribute to predict disease progression (Hicks \& Flaitz, 2005).

In this study we have prospectively examined a group of $\mathrm{LCH}$ adult patients in order to define the occurrence of oral and periodontal lesions; characterisation of local disease, response to treatment and relation with systemic involvement and therapy have been also addressed. 


\section{PATIENTS AND METHODS}

A group of 31 patients affected by LCH were studied. Patients were consecutively referred to us between 1989 and 2007 by the Haematology Department of the University "La Sapienza", where they had the LCH diagnosis confirmed by immuno-histopathology, and the disease extent staged by complete work up including skeletal survey, skull series, bone scan, complete blood count, sedimentation rate, liver function tests, electrolytes, and urinalysis. Particular attention was paid to ascertain "risk" organs involvement. According to the number of involved organs, systemic involvement was classified as unisystemic (involvement of a single organ) or multisystemic (two or more organs involved); within each organ the disease was categorized as unifocal or multifocal according to the number of lesions (one or more than one lesion, respectively).

Patients were already receiving the appropriate systemic therapy when evaluation for oral lesions started. At the first oral evaluation patients underwent thorough clinical oral examination, full mouth periodontal probing, intra-oral and panoramic radiograph, and computed tomography (CT) of jawbones with Dentascan imaging reformatting. Patients were then included in a follow up program and recalled every six months; at each recall visit patients' oral status, and especially the presence of oral lesions, was assessed by means of clinical examination of oral mucosa, periodontal examination (probing pocket depth, clinical attachment loss, full mouth plaque and bleeding scores), panoramic and intra-oral radiographs. In particular, periodontal damage by LCH was defined by the presence of increased probing pocket depth, attachment loss and/or bone resorption, and confirmed by histopathology. The clinical evaluation was performed every time by more than a clinician, but not always the same, with different expertise (oral mucosa, bone, periodontal lesions). Whenever oral lesions and/or radiographic abnormalities were found adequate additional investigations, including histopathologic and laboratory examination, were performed and the diagnosis confirmed as LCH; convenient therapeutic measures were undertaken and the frequency of follow up recalls accordingly modified. All data were collected and stored using standardized forms.

\section{RESULTS}


The study group (Tab.1) included 16 (51.6\%) females and 15 (48.4\%) males. Patients' age at the first diagnosis of LCH ranged between 18 and 73, with a mean age of 37.3 years and a median of 36 years. According to organs involvement (Tab.1), patients were stratified in different categories of disease extent: 20/31 and 11/31 had unisystemic and multisystemic disease, respectively. Unisystemic disease involved bone in $45 \%$ of cases and internal organs in $55 \%$ of patients: multifocal lesions were prevalent and accounted for 55\% and $90 \%$ of bone and internal organ disease, respectively. In multisystemic involvement, bone and internal organs were affected in $82 \%$ of cases (Fig.1). Skull involvement was present in 35.5\% of cases. Patients were treated according to approaches detailed in Table 1 and in $64.5 \%$ of cases remission was obtained. Six patients (19.3\%) dropped out from the study (three moved elsewhere, three came from distant regions and decided to continue the follow up for the systemic disease in a nearer haematological disease centre), but they were responsive to treatment while followed up. Only one patient (3.2\%) showed relapsing disease, while two $(6.4 \%)$ experienced progression of the disease, but they had a very small follow up period (0.6 years). Two patients died during the study; death was related to causes other than $\mathrm{LCH}$ in one case, while in the other patient it occurred because of pulmonary complications due to lung multifocal LCH involvement. 12 patients of the study group (38.7\%) developed oral LCH lesions during the follow up (Tab.2). The observation period ranged between 0.6 and 18 years, with a mean of 5.73 years (Tab.1); in particular, patients in whom oral lesions occurred had a mean follow up of 8.45 years. In 7 out of the 12 patients (58.3\%) both mandible and maxilla were affected and all of them, except one, had multifocal jawbone involvement; 3 (25\%) patients showed posterior mandible unifocal involvement, whereas two (16.7\%) had posterior maxilla location of LCH (both as single and multiple lesions). Lesions appeared as punched out or ill-defined radiolucencies without a corticated rim (Fig.2). Posterior regions of the jawbones were always affected. The involvement of anterior regions was not constant; however, whenever present, it was always observed in association with the involvement of posterior regions. It is worth noting that anterior and posterior lesions were not contiguous but separated by unaffected tissues. Oral/periodontal lesions were present in 5 patients with multisystemic disease (4 with unifocal involvement), and in 7 cases with unisystemic disease (6 had multifocal lesions in the affected organ: internal organs in 3 cases, bones in 2 cases, skin in one case) (Tab.1, Tab.2).

Oral disease was associated with pain in $83.4 \%$ of cases without predilection for bone and/or soft tissues involvement. Clinical signs included oral soft tissues ulcers affecting the gingiva (Fig.3) and/or the alveolar mucosa (50\%; half of which overlying bone lesions); ulcers were sometimes associated with proliferative exuberant tissue, producing variable clinical pictures in which tissue destruction and tissue exuberance coexisted (Fig.4). Other signs were gingival bleeding (66.7\%), 
periodontal damage (50\%) in affected teeth of affected areas, tooth mobility (16.7\%), non-healing extraction sockets $(8.3 \%)$.

In a completely asymptomatic case $(8.3 \%)$ the lesion was discovered by means of an oral x-ray examination made for other reasons. Only one patient (8.3\%) was treated with systemic chemotherapy, two (16.7\%) with soft tissues excision, two (16.7\%) by means of surgical curettage and the others $(58.3 \%)$ with a combination of teeth extraction, surgical curettage and in one case with intralesional administration of $\alpha$-interferon. If we consider oral lesions (both bone and soft tissues lesions) we had complete healing in all cases. However, in two patients that have been successfully treated for their systemic disease (16.7\%), after treatment and healing of initial oral lesions, we had secondary new oral lesions; these, confirmed as LCH by immunohistopathology, occurred in a different location (same side but more anterior sites), with the same appearance (mucosal ulceration in one case and a small mass with focal ulceration in the other) of previous lesions.

\section{DISCUSSION}

The main role in treating LCH patients is taken by oncologist/haematologist because of the current view of its clonal proliferative etiopathogenesis(Willman et al., 1994, Willman \& McClain, 1998); however, due to the possible widespread involvement of multiple organ systems, a team approach may be appropriate and advisable in disease diagnosis, staging, treatment and follow up. Thus, addressing oral and periodontal manifestations should be included in patients' evaluation and management. In fact, even if bone and mucosae have been classified as non-risk organs, their involvement may carry a 40.7 relative risk of disease progression(Howarth et al., 1999). In addition, in the particular case of oral location, lesions are associated with a variety of signs, symptoms and loss of function, which may significantly impair the quality of life.

In our prospective study, $38.7 \%$ of patients developed oral $\mathrm{LCH}$, while the remaining 19 patients (61.3\%), followed up for a mean of 4.02 years (range 0.6-18), remained free from oral lesions. This rate of occurrence is in accordance with other prospective studies and reports(Sigala et al., 1972, Arico et al., 2003, Arico, 2004); however, the frequency of oral involvement reported in literature ranges between 4.5\%(Blevins et al., 1959) and 86\%(Bartnick et al., 2002). This wide variation may be explained by the heterogeneity of case series as regards the case definition, the length of follow up and the stratification for patients' age; under the latter point of view, the most of data belong to paediatric literature. In our series only adult patients are considered. In the present study patients 
were not assessed by the same clinician at each follow up evaluation, but all the reported lesions were diagnosed by means of clinical, radiological, laboratory, and histopathological procedures; thus, within this standardized diagnostic work-up, inter-examiner or intra-examiner variability has little chance to significantly alter results.

Oral manifestations include signs and symptoms involving bone, periodontium and oral soft tissues, with pain and gingival bleeding/ulceration being the most frequent as reported in other series(Hartman, 1980, Schepman et al., 1998). These can cause a significant loss of oral function and detrimental effects in patients' quality of life, as well as aesthetics impairment when anterior regions are involved. In the majority of patients (58.3\%), oral lesions involved, both the mandible and the maxilla in a multifocal pattern; in addition, a preference for posterior regions was observed. In particular, the absence of isolated anterior lesions let us speculate that posterior regions may be interested in earlier phases of the disease. From a clinical point of view, this could mean that whenever involvement of anterior regions of jawbones is discovered, a careful evaluation should be always carried on in order to exclude the presence of posterior lesions. The analysis of data shows that unifocal oral involvement is significantly associated with multisystemic disease while multifocal oral lesions are associated with unisystemic involvement (chi-square test, $\mathrm{p}<0.05$ ). This may seem a bit contradictory but we have no explanation for it. The only implication that we can draw from this finding is that attention should be deserved for oral unifocal involvement; in fact, the control of local lesions may be easier, but patient prognosis might be worse due to the multisystemic disease. Oral and periodontal lesions were easily handled with local measures (Tab.2). In particular, bone disease was treated by surgical curettage; this was associated with teeth extraction when periodontal damage caused by histiocytosis infiltration was present, and excision of involved soft tissues. Only one case received intralesional injection of $\alpha$-interferon in order to treat a localized oral mucosa lesion. In fact, $\alpha$-interferon promotes the terminal differentiation of histiocytes and dendritic cells; it has proved to be most efficacious in small tumour masses(Simko \& Nagy, 1996), and its efficacy in the therapy of LCH has been suggested to coincide with the expression and activation of the protein kinase $\mathrm{C}$-a signalling pathway in LCH-histiocytes(Brown, 2003). As regards the patient receiving systemic chemotherapy, it is important to note that this was intended not to treat oral lesions but systemic disease. In fact, the patient was diagnosed with $\mathrm{LCH}$ few months before and was still under active treatment for systemic disease control. Systemic medications were useful also in healing oral lesions, but soon a new different oral site was involved. We can speculate that this occurred because systemic disease, and oral lesions included in its spectrum, was not completely controlled yet. On the other hand, the second patient who experienced a new oral lesion after treatment had a stable systemic disease since many years. The 
oral lesion was again controlled by local measures and the adjusted follow up showed no systemic relapses without any other systemic treatment; nonetheless, it is not possible to completely rule out that the new oral lesion might be considered the first sign of disease reactivation.

\section{Authors' statements \\ The authors disclose that they have no conflict of interest related to this study. \\ The study was funded by authors' own Institutions.}




\section{REFERENCES}

Arico M (2004). Langerhans cell histiocytosis in adults: more questions than answers? Eur $J$ Cancer 40: 1467-73.

Arico M, Girschikofsky M, Genereau T, Klersy C, McClain K, Grois N, Emile JF, Lukina E, De Juli E \& Danesino C (2003). Langerhans cell histiocytosis in adults. Report from the International Registry of the Histiocyte Society. Eur J Cancer 39: 2341-8.

Bartnick A, Friedrich RE, Roeser K \& Schmelzle R (2002). Oral Langerhans cell histiocytosis. $J$ Craniomaxillofac Surg 30: 91-6.

Baumgartner I, von Hochstetter A, Baumert B, Luetolf U \& Follath F (1997). Langerhans'-cell histiocytosis in adults. Med Pediatr Oncol 28: 9-14.

Blevins C, Dahlin DC, Lovestedt SA \& Kennedy RL (1959). Oral and dental manifestations of histiocytosis X. Oral Surg Oral Med Oral Pathol 12: 473-83.

Brown RE (2003). Interferon-alpha therapy, protein kinase C-alpha and Langerhans cell histiocytosis. Med Pediatr Oncol 41: 63-4.

Devaney KO, Putzi MJ, Ferlito A \& Rinaldo A (1997). Head and neck Langerhans cell histiocytosis. Ann Otol Rhinol Laryngol 106: 526-32.

Favara BE \& Jaffe R (1994). The histopathology of Langerhans cell histiocytosis. Br J Cancer Suppl 23: S17-23.

Giona F, Caruso R, Testi AM, Moleti ML, Malagnino F, Martelli M, Ruco L, Giannetti GP, Annibali S \& Mandelli F (1997). Langerhans' cell histiocytosis in adults: a clinical and therapeutic analysis of 11 patients from a single institution. Cancer 80: 1786-91.

Hartman KS (1980). Histiocytosis X: a review of 114 cases with oral involvement. Oral Surg Oral Med Oral Pathol 49: 38-54.

Hicks J \& Flaitz CM (2005). Langerhans cell histiocytosis: current insights in a molecular age with emphasis on clinical oral and maxillofacial pathology practice. Oral Surg Oral Med Oral Pathol Oral Radiol Endod 100: S42-66.

Howarth DM, Gilchrist GS, Mullan BP, Wiseman GA, Edmonson JH \& Schomberg PJ (1999). Langerhans cell histiocytosis: diagnosis, natural history, management, and outcome. Cancer $\mathbf{8 5}$ : 2278-90.

Malpas JS \& Norton AJ (1996). Langerhans cell histiocytosis in the adult. Med Pediatr Oncol 27: 540-6.

McClain K (1999-2005.). Adult Langerhans Cell Histiocytosis. Histiocyte Society. "www.histio.org/society/LCH/Adult/mcclain2.shtml".

Milian MA, Bagan JV, Jimenez Y, Perez A, Scully C \& Antoniades D (2001). Langerhans' cell histiocytosis restricted to the oral mucosa. Oral Surg Oral Med Oral Pathol Oral Radiol Endod 91 : 76-9.

Schepman KP, Radden BG \& Van der Waal I (1998). Langerhans' cell histiocytosis of the jaw bones. Report of 11 cases. Aust Dent J 43: 238-41.

Sigala JL, Silverman S, Jr., Brody HA \& Kushner JH (1972). Dental involvement in histiocytosis. Oral Surg Oral Med Oral Pathol 33: 42-8.

Simko R \& Nagy K (1996). Interferon-alpha in childhood haematological malignancies. Postgrad Med J 72: 709-13.

Willman CL, Busque L, Griffith BB, Favara BE, McClain KL, Duncan MH \& Gilliland DG (1994). Langerhans'-cell histiocytosis (histiocytosis X)--a clonal proliferative disease. $N$ Engl J Med 331: 154-60.

Willman CL \& McClain KL (1998). An update on clonality, cytokines, and viral etiology in Langerhans cell histiocytosis. Hematol Oncol Clin North Am 12: 407-16. 


\section{FIGURE LEGENDS}

Figure 1: Organ involvement in adult LCH patients.

Figure 2: Radiographic appearance of mandibular bone LCH lesions.

Figure 3: Clinical appearance of gingival LCH lesions (same case in fig.2).

Figure 4: $\mathrm{LCH}$ lesion extending to alveolar mucosa; note ulcerations associated with proliferative exuberant tissue.

Figure 5: A) dense infiltration by clusters of eosinophils and mononuclear cells. The surface epithelium is ulcerated with exocytose and granulocytic microabscesses (HaematoxylinEosin, 10X).

B) Immunophenotyping: positivity for CD1a antigen. (LSAB-HRP, nuclear counterstaining with haematoxylin, 10X). 


\begin{tabular}{|c|c|c|c|c|c|c|c|}
\hline $\begin{array}{l}\text { Systemic } \\
\text { involvement }\end{array}$ & Case & $\begin{array}{c}\text { Age at first } \\
\text { diagnosis }\end{array}$ & Sex & Involved Organs & Therapy & $\begin{array}{c}\text { Disease } \\
\text { status }\end{array}$ & $\begin{array}{c}\text { Follow up } \\
\text { (years) }\end{array}$ \\
\hline \multicolumn{8}{|l|}{ UNISYSTEM } \\
\hline \multirow[t]{5}{*}{ Unifocal } & 1 & 28 & $\mathrm{~F}$ & skull & PDN & Drop out & 1 \\
\hline & 2 & 33 & $\mathrm{~F}$ & skull & PDN & Drop out & 5.7 \\
\hline & 3 & 36 & $\mathrm{M}$ & skull & PDN & Progression & 0.6 \\
\hline & 4 & 42 & $\mathrm{~F}$ & lymphnodes & PDN & Remission & 0.6 \\
\hline & 5 & 40 & M & clavicle & RAD & Remission & 0.6 \\
\hline \multirow[t]{15}{*}{ Multifocal } & 6 & 18 & M & skull, hip, scapula & $\mathrm{VBL}+\mathrm{PDN}$ & Drop out & 18 \\
\hline & 7 & 19 & $\mathrm{M}$ & lung & PDN & Remission & 13 \\
\hline & 8 & 22 & $\mathrm{~F}$ & lung & PDN & Drop out & 6 \\
\hline & 9 & 22 & $\mathrm{~F}$ & abdominal lymphnodes & PDN & Remission & 4.1 \\
\hline & 10 & 26 & M & lung & IFN & Remission & 13 \\
\hline & 11 & 34 & M & lung & PDN & Remission & 5.5 \\
\hline & 12 & 38 & $\mathrm{M}$ & lung & VBL + HDMP & Remission & 11 \\
\hline & 13 & 39 & $\mathrm{~F}$ & ilium & VBL & Remission & 13 \\
\hline & 14 & 43 & $\mathrm{M}$ & femur, ilium & VBL + HDMP & Remission & 18 \\
\hline & 15 & 45 & M & lung & VBL + HDMP & Remission & 5 \\
\hline & 16 & 51 & $\mathrm{M}$ & lung & VBL + HDMP & Died & 8 \\
\hline & 17 & 71 & $\mathrm{~F}$ & skin & VBL & Died & 4.6 \\
\hline & 18 & 40 & $\mathrm{~F}$ & skull & PDN & Remission & 0.6 \\
\hline & 19 & 29 & $\mathrm{~F}$ & hypophysis, lung & VBL + HDMP & Remission & 0.6 \\
\hline & 20 & 22 & M & skull, ribs, scapula & VBL + PDN & Remission & 0.6 \\
\hline \multicolumn{8}{|c|}{ MULTISYSTEM } \\
\hline \multirow[t]{5}{*}{ Unifocal } & 21 & 18 & M & skull, hypophysis & VBL + HDMP & Remission & 14 \\
\hline & 22 & 18 & $\mathrm{~F}$ & skull, lung, vulva & $\begin{array}{l}\text { VP-16 + } \\
\text { HDMP }\end{array}$ & Relapse & 14 \\
\hline & 23 & 36 & $\mathrm{~F}$ & lung, ribs & PDN & Remission & 4.2 \\
\hline & 24 & 39 & $\mathrm{M}$ & skin, tibia, omerus & IFN & Drop out & 1 \\
\hline & 25 & 46 & $\mathrm{M}$ & bone, lung & VBL + HDMP & Drop out & 4.2 \\
\hline \multirow[t]{6}{*}{ Multifocal } & 26 & 57 & $\mathrm{~F}$ & lung, vulva & VBL + HDMP & Remission & 8 \\
\hline & 27 & 72 & $\mathrm{~F}$ & skull, hypophysis & PDN & Progression & 0.6 \\
\hline & 28 & 37 & $\mathrm{~F}$ & lung, skull & PDN & Remission & 0.6 \\
\hline & 29 & 73 & $\mathrm{~F}$ & lung, skull & PDN & Remission & 0.6 \\
\hline & 30 & 34 & $\mathrm{~F}$ & $\begin{array}{l}\text { neck lymphnodes, } \\
\text { hypophysis }\end{array}$ & PDN & Remission & 0.6 \\
\hline & 31 & 29 & M & $\begin{array}{l}\text { hypophysis, skull, lung, } \\
\text { femur, tibia }\end{array}$ & $\mathrm{VBL}+\mathrm{PDN}$ & Remission & 0.6 \\
\hline
\end{tabular}

VBN: vinblastina; PDN: prednisone; IFN: $\alpha$-interferone; HDMP: methilprednisolone; VP-16: etoposide; RAD: radiotherapy. 
Table 2: Clinical features of oral LCH involvement in adult patients.

\begin{tabular}{|c|c|c|c|c|c|c|c|}
\hline \multirow[t]{3}{*}{ Case } & \multicolumn{4}{|c|}{ Oral involvement } & \multirow{3}{*}{$\begin{array}{c}\text { Oral } \\
\text { lesions }\end{array}$} & \multirow{3}{*}{$\begin{array}{l}\text { Therapy for } \\
\text { oral disease }\end{array}$} & \multirow{3}{*}{$\begin{array}{c}\text { Oral } \\
\text { lesions } \\
\text { Outcome* }\end{array}$} \\
\hline & \multicolumn{2}{|c|}{ Maxilla } & \multicolumn{2}{|c|}{ Mandible } & & & \\
\hline & anterior & posterior & anterior & posterior & & & \\
\hline 1 & - & - & - & + & single & $\mathrm{SC}$ & $\begin{array}{l}\text { Complete } \\
\text { Response }\end{array}$ \\
\hline 7 & - & - & - & + & single & $\mathrm{SC}$ & $\begin{array}{l}\text { Complete } \\
\text { Response }\end{array}$ \\
\hline 10 & - & + & - & + & multiple & $\mathrm{TE}+\mathrm{SC}+\mathrm{IFN}$ & $\begin{array}{l}\text { Complete } \\
\text { Response }\end{array}$ \\
\hline 13 & - & + & + & + & multiple & $\mathrm{TE}+\mathrm{SC}+\mathrm{STE}$ & $\begin{array}{l}\text { New oral } \\
\text { lesion }\end{array}$ \\
\hline 14 & - & + & - & + & multiple & $\mathrm{TE}+\mathrm{SC}$ & $\begin{array}{l}\text { Complete } \\
\text { Response }\end{array}$ \\
\hline 15 & - & + & - & - & multiple & STE & $\begin{array}{l}\text { Complete } \\
\text { Response }\end{array}$ \\
\hline 17 & + & + & + & + & single & $\mathrm{TE}+\mathrm{SC}$ & $\begin{array}{l}\text { Complete } \\
\text { Response }\end{array}$ \\
\hline 21 & - & - & - & + & single & $\mathrm{TE}+\mathrm{SC}$ & $\begin{array}{l}\text { Complete } \\
\text { Response }\end{array}$ \\
\hline 22 & - & + & - & + & multiple & $\mathrm{TE}+\mathrm{SC}$ & $\begin{array}{l}\text { Complete } \\
\text { Response }\end{array}$ \\
\hline 24 & + & + & + & + & multiple & $\mathrm{TE}+\mathrm{SC}$ & $\begin{array}{l}\text { Complete } \\
\text { Response }\end{array}$ \\
\hline 25 & - & + & - & - & single & STE & $\begin{array}{l}\text { Complete } \\
\text { Response }\end{array}$ \\
\hline 27 & - & + & + & + & multiple & $\begin{array}{l}\text { Systemic } \\
\text { Chemotherapy }\end{array}$ & $\begin{array}{l}\text { New oral } \\
\text { lesion }\end{array}$ \\
\hline
\end{tabular}

TE: teeth extraction

SC: surgical curettage

IFN: local $\alpha$-interferon

STE: soft tissues excision

*: to the last follow up visit 
Figure 1: Organ involvement in adult LCH patients. $190 \times 142 \mathrm{~mm}$ (96 x $96 \mathrm{DPI})$ 
Figure 2: Radiographic appearance of mandibular bone LCH lesions. $292 \times 247 \mathrm{~mm}(72 \times 72 \mathrm{DPI})$ 


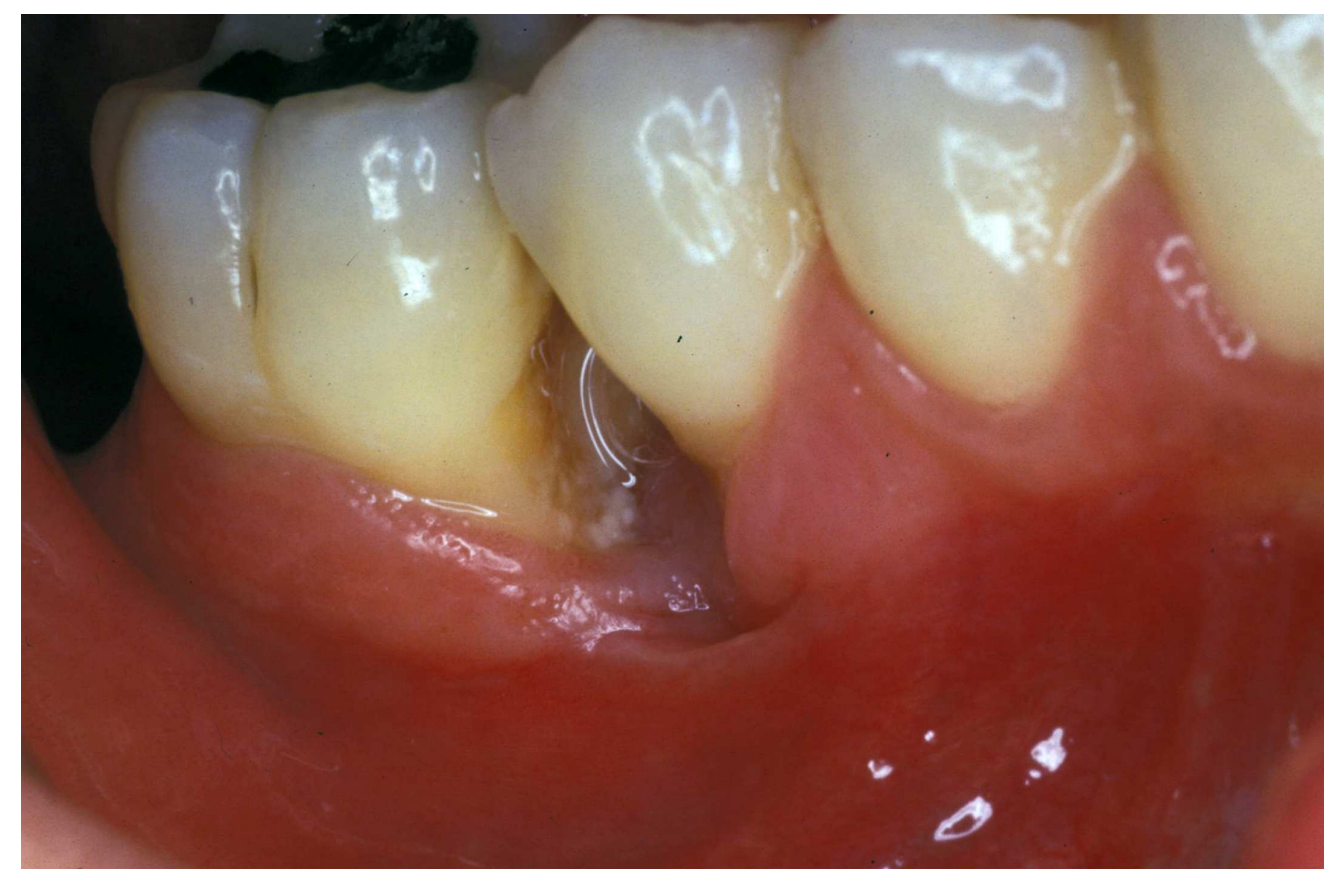

Figure 3: Clinical appearance of gingival LCH lesions (same case in fig.2). $137 \times 90 \mathrm{~mm}(400 \times 400 \mathrm{DPI})$ 


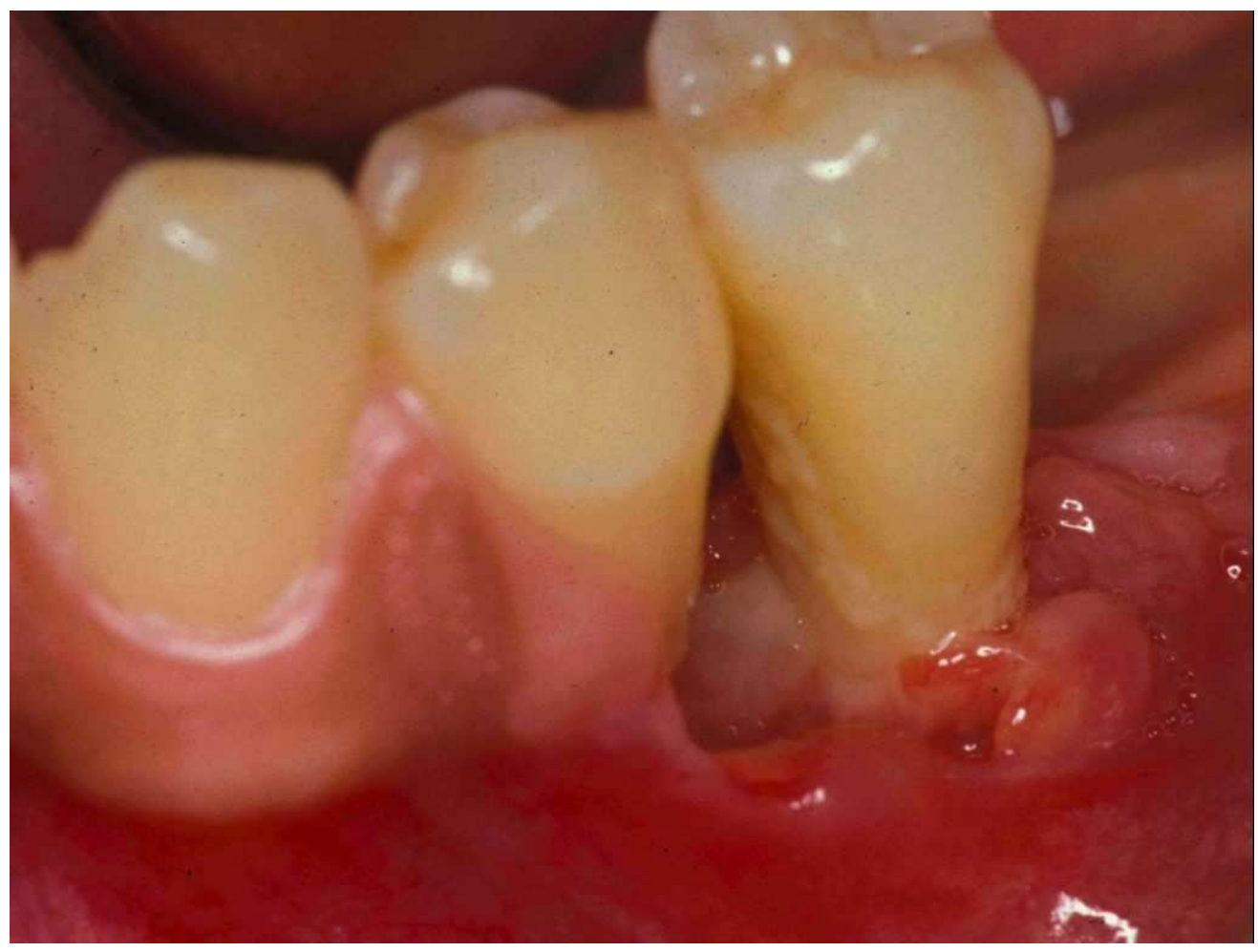

Figure 4: LCH lesion extending to alveolar mucosa; note ulcerations associated with proliferative exuberant tissue.

$361 \times 270 \mathrm{~mm}(72 \times 72 \mathrm{DPI})$ 
Figure 5: A) dense infiltration by clusters of eosinophils and mononuclear cells. The surface epithelium is ulcerated with exocytose and granulocytic microabscesses (Haematoxylin-Eosin, 10X).

B) Immunophenotyping: positivity for CD1a antigen. (LSAB-HRP, nuclear counterstaining with haematoxylin, 10X). $361 \times 270 \mathrm{~mm}(72 \times 72$ DPI) 